\title{
Corneal Endothelium
}

National Cancer Institute

\section{Source}

National Cancer Institute. Corneal Endothelium. NCI Thesaurus. Code C12707.

A single layer of specialized, flat, mitochondria-rich cells that line the posterior surface of the cornea, which govern fluid and solute transport across the posterior surface of the cornea. 